\title{
JURIIII
}

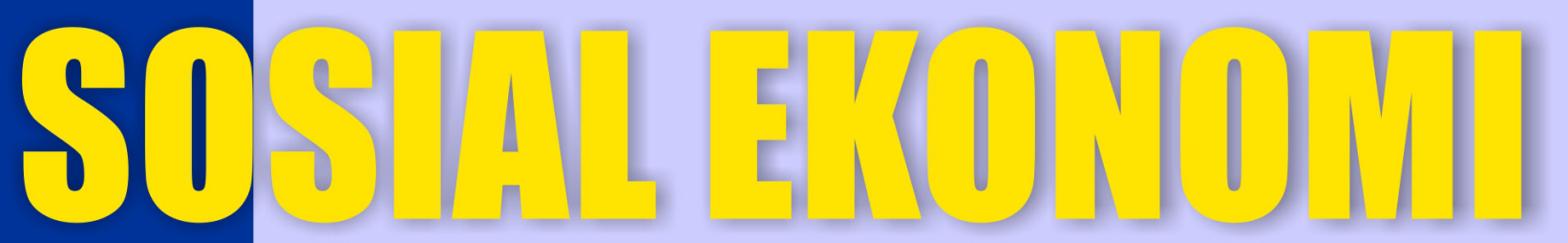

\section{KELAUTIAN DAWMPRRIANAW}

J. Sosial Ekonomi Kelautan dan Perikanan

Vol. 12

No. 2

Hal. $133-253$

Jakarta
Desember 2017

ISSN
$2088-8449$

TERAKREDITASI dengan Nomor Akreditasi: 741/AU3/P2MI-LIPI/04/2016

Diterbitkan bersama :

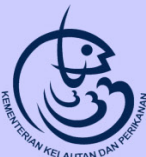

Balai Besar Riset Sosial Ekonomi Kelautan dan Perikanan

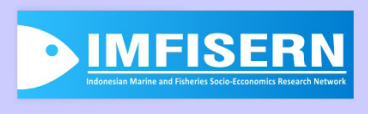

Jaringan Riset Sosial Ekonomi Kelautan dan Perikanan 


\section{JURNAL SOSIAL EKONOMI KELAUTAN DAN PERIKANAN}

\section{Volume 12 Nomor 2, Desember 2017}

\section{Penanggung Jawab :}

Kepala Balai Besar Riset Sosial Ekonomi Kelautan dan Perikanan

\section{Dewan Redaksi :}

\section{Ketua:}

Prof. Dr. Sonny Koeshendrajana (Ekonomi Sumberdaya Kelautan dan Perikanan)

\section{Anggota:}

Prof. Dr. I. Wayan Rusastra (Ekonomi Pertanian)

Dr. Achmad Zamroni (Pengelolaan Wilayah Pesisir)

Dr. Rilus A. Kinseng (Sosiologi)

Dr. Zuzy Anna (Ekonomi Sumberdaya Alam)

\section{Mitra Bestari :}

Prof. Dr. Tridoyo Kusumastanto (Institut Pertanian Bogor)

Prof. Pantjar Simatupang (PSE - Kementerian Pertanian)

Dr. Agus Heri Purnomo (Puslitbang DSPBKP - KKP)

Dr. Dedi S. Adhuri (PMB-LIPI)

Ir. Sumardi Suriatna (Komisi Penyuluhan Perikanan Nasional)

\section{Redaksi Pelaksana :}

Sinta Nurwijayanti, S.Pi, M.SE., M.A

Tenny Apriliani, M.Si

Fatriyandi Nur Priyatna, M.Si

Risna Yusuf, M.Si

Andrian Ramadhan, MT

Edwin Yulia Setyawan, S.T

Asep Jajang Setiadi, S.Pi

Ilham Ferbiansyah, S. Kom

\section{Alamat Redaksi :}

Balai Besar Riset Sosial Ekonomi Kelautan dan Perikanan

Gedung Balitbang KP Lt. 3

Jalan Pasir Putih Nomor 1 Ancol Timur, Jakarta Utara

Telp. (021) 6471 1583, Faks.(021) 64700924

Email: pt.sosek@gmail.com

Jurnal Online: http://ejournal-balitbang.kkp.go.id/index.php/sosek 


\section{KATA PENGANTAR}

Puji syukur kami panjatkan kepada Tuhan Yang Maha Esa karena berkat rahmat-Nya, Jurnal Kebijakan dan Riset Sosial Ekonomi Kelautan dan Perikanan yang berganti nama menjadi Jurnal Sosial Ekonomi Kelautan dan Perikanan dengan tampilan dan tata letak baru telah diterbitkan.

Jurnal Sosial Ekonomi Kelautan dan Perikanan sesuai dengan Keputusan Lembaga IImu Pengetahuan Indonesia 329/E/2016 tertanggal 24 Maret 2016, telah terakreditasi dengan Nomor Akreditasi: 741/AU3/P2MI-LIPI/04/2016.

Guna peningkatan nilai akreditasi di masa mendatang maka Jurnal Sosial Ekonomi Kelautan dan Perikanan Vol. 12 No. 2 Tahun 2017 telah mengalami perbaikan-perbaikan sesuai dengan saran dan petunjuk dari Tim Akreditasi Jurnal Pusat Dokumentasi IImiah Indonesia - Lembaga IImu Pengetahuan Indonesia (PDII LIPI).

Pada edisi kali ini, ditampilkan sepuluh karya tulis ilmiah yang meliputi; (i) Kerugian Sumber Daya Ikan Akibat Praktik Mark Down Kapal Penangkap Ikan di Indonesia; (ii) Analisis Finansial Beberapa Metoda Budidaya Bandeng dan Udang Secara Mono dan Poli Kultur (Studi Kasus di Kecamatan Blanakan, Kabupaten Subang); (iii) Minimalisasi Biaya Distribusi Industri Pengolahan Produk Perikanan: Aplikasi Transportasi Program Solver; (iv) Analisis Resiko Usaha Pabrik Pakan Ikan Mandiri; (v) Dampak Kinerja Buruh Terhadap Waktu Tunggu dan Tingkat Pemanfaatan Dermaga Sandar di PPP Tegalsari; (vi) Pemberdayaan Pengolah Ikan Skala Rumah Tangga di Provinsi Jawa Barat; (vii) Peran Perempuan Nelayan Dalam Usaha Perikanan Tangkap dan Peningkatan Ekonomi Rumah Tangga Pesisir Teluk Jakarta; (viii) Dampak Keberadaan Industri Semen Terhadap Sistem Mata Pencaharian (Livelihood System) Nelayan Bayah; (ix) Analisis Faktor-Faktor yang Mempengaruhi Perubahan Pendapatan Nelayan Akibat Variabilitas Iklim (Kasus : Desa Muara Kecamatan Blanakan Kabupaten Subang); (x) Indeks Sosial Ekonomi Rumah Tangga Nelayan Indonesia.

Dengan diterbitkannya jurnal ini, diharapkan dapat memberikan informasi hasil penelitian di bidang sosial ekonomi yang ada kepada masyarakat dan menambah wawasan ilmu pengetahuan di bidang sosial ekonomi kelautan dan perikanan bagi akademisi dan peneliti. Saran dan masukan dari pembaca sangat diharapkan guna kesempurnaan penerbitan jurnal di masa mendatang. 


\section{JURNAL SOSIAL EKONOMI KELAUTAN DAN PERIKANAN Volume 12 Nomor 2, Tahun 2017}

\section{DAFTAR ISI}

KATA PENGANTAR

DAFTAR ISI

INDEKS ABSTRAK

KERUGIAN SUMBER DAYA IKAN AKIBAT PRAKTIK MARK DOWN KAPAL PENANGKAP IKAN DI INDONESIA

Oleh : Maulana Firdaus, Yesi Dewitasari, Radityo Pramoda dan Sonny Koeshendrajana

ANALISIS FINANSIAL BEBERAPA METODA BUDIDAYA BANDENG DAN UDANG SECARA MONO DAN POLI KULTUR

(Studi Kasus di Kecamatan Blanakan, Kabupaten Subang)

Oleh : Admi Athirah, Tarunamulia, Ruzkiah Asaf dan Akhmad Mustafa

MINIMALISASI BIAYA DISTRIBUSI INDUSTRI PENGOLAHAN PRODUK PERIKANAN: APLIKASI TRANSPORTASI PROGRAM SOLVER

Oleh : Risna Yusuf dan Yayan Hikmayani

ANALISIS RESIKO USAHA PABRIK PAKAN IKAN MANDIRI

Oleh : Budi Wardono, Rikrik Rahadian dan Tajerin

DAMPAK KINERJA BURUH TERHADAP WAKTU TUNGGU DAN TINGKAT PEMANFAATAN DERMAGA SANDAR DI PPP TEGALSARI

Oleh : Suryanto, Ignatius Tri Hargiyatno, Sandi Wibowo dan Setiya Triharyuni

PEMBERDAYAAN PENGOLAH IKAN SKALA RUMAH TANGGA

DI PROVINSI JAWA BARAT

Oleh : Yaya Hudaya, Aida Vitayala S. Hubeis, Basita G. Sugihen dan Anna Fatchiya ......

PERAN PEREMPUAN NELAYAN DALAM USAHA PERIKANAN TANGKAP

DAN PENINGKATAN EKONOMI RUMAH TANGGA PESISIR TELUK JAKARTA

Oleh : Nurlaili dan Rizky Muhartono

DAMPAK KEBERADAAN INDUSTRI SEMEN TERHADAP SISTEM MATA PENCAHARIAN (LIVELIHOOD SYSTEM) NELAYAN BAYAH

Oleh : Yunia Rahayuningsih

ANALISIS FAKTOR-FAKTOR YANG MEMPENGARUHI PERUBAHAN

PENDAPATAN NELAYAN AKIBAT VARIABILITAS IKLIM

(Kasus : Desa Muara Kecamatan Blanakan Kabupaten Subang)

Oleh : Azizi, Eka Intan Kumala Putri dan Achmad Fahrudin

INDEKS SOSIAL EKONOMI RUMAH TANGGA NELAYAN INDONESIA

Oleh : Andrian Ramadhan, Christina Yuliati dan Sonny Koeshendrajana
$225-233$

Halaman

iii $-\mathrm{x}$

$133-141$

$143-150$

$151-162$

$163-176$

$177-188$

$189-202$

$203-212$

$213-223$
$235-253$ 


\title{
INDEKS ABSTRAK JURNAL SOSIAL EKONOMI KELAUTAN DAN PERIKANAN (ABSTRACT INDEX OF JOURNAL SOCIO-ECONOMICS MARINE AND FISHERIES)
}

Vol. 12 No. 2, Desember 2017

\section{KERUGIAN SUMBER DAYA IKAN AKIBAT PRAKTIK MARK DOWN KAPAL PENANGKAP IKAN DI INDONESIA}

\author{
Fish Resources Losses Due to Mark Down Fishing Vessel Practiced in Indonesia
}

Maulana Firdaus, Yesi Dewitasari, Radityo Pramoda dan Sonny Koeshendrajana

\begin{abstract}
ABSTRAK
Dampak praktik Illegal Unreported and Unregulated Fishing (IUUF) telah mengakibatkan terganggunya pengelolaan pemanfaatan perikanan yang berkelanjutan dan menimbulkan kerugian ekonomi. Praktik mark down ukuran kapal penangkapan ikan merupakan salah satu penyalahgunaan perizinan dalam konteks praktik IUUF. Penelitian ini bertujuan untuk mengkaji nilai kerugian sumber daya ikan (deplesi sumber daya) akibat praktik "mark down" ukuran kapal penangkap ikan yang dilakukan di Indonesia. Penelitian dilaksanakan pada bulan Maret - April 2017 bersifat 'desk study' dan dilengkapi dengan kajian literature terkait. Data sekunder dan primer digunakan dalam penelitian ini. Analisis data dilakukan melalui Pendekatan Surplus Produksi Model Schaefer digunakan dalam penelitian ini. Nilai kerugian sumber daya ikan diketahui berdasarkan nilai deplesinya. Nilai deplesi sumber daya menggunakan pendekatan The Net Price Method. Hasil penelitian menunjukkan bahwa adanya praktik "mark down" telah menyebabkan deplesi sumber daya ikan atau pengurangan aset sumber daya ikan di perairan Indonesia. Besarnya nilai deplesi sumber daya pada tahun 2015 mencapai 9,83 trilyun rupiah dan diprediksi pada tahun 2020 meningkat menjadi 14,55 trilyun rupiah. Kajian merekomendasikan perlunya percepatan pengukuran ulang kapal perikanan dan penerapan sangsi yang tegas terhadap pelanggar sehingga tata kelola pemanfaatan sumber daya perikanan tangkap yang baik yang mampu mewujudkan pengelolaan perikanan yang berkelanjutan di Indonesia.
\end{abstract}

Kata Kunci: perikanan tangkap, IUU fishing, mark down, kapal penangkap ikan

\section{ABSTRACT}

The impact of IUU fishing has resulted in management disorder of sustainable fisheries and it caused economic loss. Markdown in vessels size is one type of manipulation practices of license in IUU fishing. This study aims to analyze the loss value of fish resources (resource depletion) due to the "markdown" practices in Indonesia. The study was basically a desk study completmenting with relevant literatures review during March - April 2015. Primary and secondary data were used in this study. Data were analyzed using the Schaefer surplus production model approached. Loss value of fish resources was estimated in terms of depletion resource value using the Net Price Method. The research found that "mark down" has led to depletion or reduction of fish resources in Indonesian waters. The estimated value of resource depletion in 2015 reached 9.83 trillion rupiahs and it is predicted to rise into 14.55 trillion rupiahs in 2020. The research suggests the need to accelerate the process of re-measuring the size of fishing vessel as well as to impose sanctions for the disobedience of the rules, so that Indonesia could have a good governance in fisheries resource management with sustainable fisheries resources.

Keywords: captured fisheries, IUU fishing, mark down, fishing vessel 


\title{
ANALISIS FINANSIAL BEBERAPA METODA BUDIDAYA BANDENG DAN UDANG SECARA MONO DAN POLI KULTUR (Studi Kasus di Kecamatan Blanakan, Kabupaten Subang)

\author{
Financial Analysis of Various Methods of Mono and Poly Culture of the Milkfish and Shrimp \\ (Case Study in Blanakan Sub-District, Subang Regency)
}

\author{
Admi Athirah, Tarunamulia, Ruzkiah Asaf dan Akhmad Mustafa
}

\section{ABSTRAK}

Bandeng dan udang merupakan komoditas utama dari hasil budidaya ikan di tambak, mempunyai potensi pengembangan yang cukup besar pada hampir semua lahan pantai di Indonesia. Penelitian ini bertujuan untuk mengkaji profil dan prospek budidaya ikan di tambak dengan menggunakan beberapa teknologi budidaya di Kabupaten Subang. Data primer dan sekunder digunakan dalam penelitian ini. Data primer diperoleh dari observasi terhadap kegiatan petambak di lokasi penelitian dan wawancara dengan bantuan kuesioner terstruktur pada responden petambak terpilih. Data sekunder diperoleh dari laporan hasil penelitian dan berbagai instansi yang terkait dengan penelitian. Analisis finansial usaha yang meliputi biaya total, pendapatan kotor, keuntungan operasional, keuntungan bersih, biaya produksi, RCRatio, BEP dan masa pengembalian modal digunakan dalam penelitian ini. Ada 4 tipe teknologi budidaya ikan yang dipraktekkan oleh petambak di Kabupaten Subang, yaitu polikultur bandeng dengan udang windu, polikultur bandeng dengan udang vaname, monokultur bandeng dan teknologi intensif udang vannamei. Hasil penelitian menunjukkan bahwa profitabilitas usaha budidaya bandeng secara monokultur menduduki posisi tertinggi yang ditunjukkan oleh nilai RC-Rasio sebesar 2.33, kemudian usaha budidaya udang vannamei intensif dengan RC-Rasio sebesar 1.88, polikultur bandeng dengan udang windu dengan RC-Ratio sebesar 1.75 dan polikultur bandeng dengan udang vannamei dengan RCRasio sebesar 1.41. Hasil tersebut menunjukkan bahwa dengan kondisi lingkungan tambak yang ada pada saat penelitian dilakukan, usaha budidaya ikan bandeng secara monokultur lebih menguntungkan dibandingkan dengan ketiga teknologi budidaya ikan lainnya.

Kata Kunci: analisis finasial, teknologi budidaya ikan di tambak, ikan bandeng, udang, Kabupaten Subang

\section{ABSTRACT}

Milkfish and shrimp are considered main commodities of pond fish culture and they have a great potential to be developed in almost all coastal area in Indonesia. This study aims to analyze pond fish culture profile and its prospect using several technologies of fish culture in Subang Regency. Primary and secondary data collection are applied in this study. Primary data were collected through observation and interview with selected fish farmer respondents using structured questionnaires. Secondary data were collected through research report and a number of related institutions. This study applied financial analysis method in terms of total cost, gross revenue, operational profit, net profit, cost of production, $R C$-Ratio, BEP and payback period. The research found that fish farmers in Subang Regency were practicing four different types of fish culture technologies, namely polyculture of milkfish with tiger prawn, polyculture of milkfish with vannamei shrimp, monoculture of milkfish, and intensive monoculture of vannamei shrimp. The result also indicated that the highest profit in terms of RC-Ratio of culture systems was monoculture of the milkfish (2.33), followed by the intensive monoculture of vannamei shrimp (1.88), polyculture of milkfish with tiger shrimp (1.75) and polyculture of milkfish with vannamei shrimp (1.41). It is concluded that monoculture of milkfish culture is more favorable compared with the other three fishpond culture technologies in the current environmental conditions.

Keywords: financial analysis, fish culture
technology, brackishwater pond, milkfish,
shrimp, Subang regency




\title{
MINIMALISASI BIAYA DISTRIBUSI INDUSTRI PENGOLAHAN PRODUK PERIKANAN: APLIKASI TRANSPORTASI PROGRAM SOLVER
}

\author{
Minimalization Distribution Cost of Fisheries Product Processing Industry: \\ The Application of Transportation in Program Solver
}

\author{
Risna Yusuf dan Yayan Hikmayani
}

\begin{abstract}
ABSTRAK
Masalah pendistribusian suatu komoditas atau produk dari sejumlah sumber ke sejumlah tujuan perlu dilakukan agar biaya pengiriman produk seminimal mungkin. Program solver merupakan salah satu software yang banyak digunakan untuk masalah optimasi misalnya dalam menyelesaikan masalah transportasi. Model transportasi berkaitan dengan penentuan rencana biaya terendah untuk mengirimkan satu barang dari sejumlah sumber pasokan ke sejumlah daerah tujuan yang menjadi sentra industri. Tujuan penelitian ini adalah mengkaji penerapan metode transportasi dengan program solver dalam meminimunkan biaya distribusi ikan yang berasal dari beberapa daerah sentra pasokan ke beberapa daerah yang menjadi sentra industri. Hasil penelitian menunjukkan bahwa efisiensi biaya distribusi yang dikeluarkan dalam mendistribusikan ikan tuna sebesar Rp. 757.983.424 dan efisiensi biaya distribusi yang dikeluarkan dalam menditribusikan ikan pelagis kecil sebesar Rp. 268.012.767. Ikan tuna dari Bitung lebih efisien didistribusikan ke Surabaya, ikan tuna dari Ternate lebih efisien didistribusikan ke Makassar, ikan tuna dari medan lebih efisien ke Surabaya, dan ikan tuna Banyuwangi lebih efisien didistribusikan ke Jakarta dan terakhir ikan tuna dari daerah pasokan lainnya dapat diditribusikan ke Makassar, Surabaya, Jakarta dan daerah tujuannya lainnya. Ikan pelagis dari Bitung lebih efisien ke Makassar, ikan pelagis dari Ternate lebih efisien ke Surabaya, ikan pelagis dari Medan lebih efisien ke Makassar dan Banyuwangi lebih efisien ke Makassar dan Surabaya, dan daerah pasokan lainnya lebih efisien ke Jakarta dan Surabaya. Implikasi penelitian dimana daerah pasokan ikan dapat lebih fokus pada daerah tertentu yang menjadi daerah tujuan mengakibatkan biaya distribusi ikan menjadi lebih efisien dan pasokan ikan di daerah tujuan menjadi lebih stabil.
\end{abstract}

Kata Kunci: metode transportasi, program solver, minimisasi biaya distribusi, ikan pelagis, industri pengolahan perikanan

\section{ABSTRACT}

Solution to distribution problem of a commodity or product is necessary in order to minimize its distribution cost. Program solver is one of the most widely used software to solve problem related to transportation. Transportation model determines distribution cost of a product from port of origin to port of destination. This research purpose is intending on analyzing the application of program solver in minimizing fish distribution cost from suppliers to industrial centers. The result showed that efficiency distribution cost of tuna was Rp. 757.983.424,and the efficiency distribution cost of small pelagic fish was Rp. 268.012.767,-. Distribution cost of tuna from Bitung to Surabaya is more efficient, distribution cost of tuna from Ternate to Makassar is more efficient, distribution cost of tuna from Medan to Surabaya is more efficient, distribution cost of tuna from Banyuwangi to Jakarta is more efficient, and distribution cost of tuna from the other ports of origin are more efficient to Makassar, Jakarta, Surabaya and the other ports of destination. Distribution cost of small pelagic fish from Bitung to Makassar is more efficient, distribution cost of small pelagic fish from Ternate to Surabaya is more efficient, distribution cost of small pelagic fish from Medan to Makassar is more efficient, distribution cost of small pelagic fish from Banyuwangi to Makassar and Surabaya is more efficient, and distribution cost of small pelagic fish from the other ports of origin are more efficient to Jakarta and Surabaya. Therefore, fish distribution from port of origin should be focused to a particular destination port in order to get more efficient distribution cost and stable fish supply in the destination area.

Keywords: transportation model, program solver, minimizing of distribution cost, pelagic, fishery processing industry 


\title{
ANALISIS RESIKO USAHA PABRIK PAKAN IKAN MANDIRI \\ Risk Analysis of The Business Self-Sufficient Fish Feed Plant
}

\author{
Budi Wardono, Rikrik Rahadian dan Tajerin
}

\begin{abstract}
ABSTRAK
Aspek keberlanjutan merupakan permasalahan utama dalam upaya pengembangan pabrik pakan ikan mandiri. Masih diperlukan berbagai upaya agar Program Gerakan Pakan Ikan Mandiri (GERPARI) mampu menjadi solusi kebutuhan pakan ikan. Analisis risiko merupakan salah satu upaya untuk mengetahui sejauh mana usaha pakan ikan mandiri dapat berkelanjutan. Tujuan penelitian untuk mengetahui tingkat risiko tentang keberlanjutan usaha dengan pendekatan NPV at risk. Penelitian dilakukan pada bulan Mei-Desember 2016, di pabrik pakan ikan di Kabupaten Sleman dan Gunungkidul, Propinsi Daerah Istimewa Yogyakarta. Data yang digunakan adalah data primer dan data sekunder. Data primer meliputi data usaha yaitu penyediaan bahan baku dan bahan lainnya, biaya produksi, pendapatan, sistem distribusi dan pemasaran pakan. Analisis yang digunakan adalah analisis risiko usaha dengan pendekatan NPV risk. Hasil analisis menunjukkan pada kondisi eksisting ternyata usaha pabrik pakan mandiri belum menguntungkan. Berdasarkan simulasi usaha pabrik pakan mandiri mampu memberikan keuntungan dengan syarat kontinuitas produksi dan bahan baku terpenuhi. Strategi yang dilakukan agar usaha memberikan margin positif dan NPV lebih besar dari 0, ialah menaikkan tingkat produksi dari $35 \%$ menjadi $50 \%$ dari kapasitas terpasang dan strategi kedua dengan menaikkan harga jual sebesar Rp. 500 menjadi Rp. 8.000/kg yang masih jauh dibawah harga pasaran.
\end{abstract}

Kata Kunci: GERPARI, investor, Margin, NPV at risk, pakan

\begin{abstract}
The sustainability aspect is a major problem in the development of community-based selfsufficient fish feed plant. Various efforts are still necessary to make the self-sufficient fish feed movement program (Gerakan Pakan Ikan Mandiril GERPARI) into a solution for the needs of fish feed. Risk analysis is one of the effort on measuring the sustainability of self-sufficient fish feed business. This research purpose was to identify the level of risk on business sustainability using the NPV at risk approach. The research was conducted in May-December 2016 at fish feed factory in Sleman and Gunungkidul regencies of Yogyakarta province. Primary and secondary data were used in this study. Primary data were in terms of raw and other materials supply, production costs, income, distribution system and marketing. Risk analysis with NPV risk approach was used in this study. Results of the study showed that fish feed business has not been profitable. Based on the simulation, self sufficient fish feed business is profitable provided that continuity of raw materials and days of production are fulfilled. Therefore, there are 2 strategies to provide positive margin and NPV greater than 0, first, increasing production rate from 35\% to $50 \%$ of installed capacity, and second, increasing the selling price by Rp. 500 to Rp. 8,000/kgs which is still far below the market price.
\end{abstract}

Keywords: GERPARI, investor, margin, NPV at risk, feed

\section{DAMPAK KINERJA BURUH TERHADAP WAKTU TUNGGU DAN TINGKAT PEMANFAATAN DERMAGA SANDAR DI PPP TEGALSARI

\author{
Impact of Labour Utility to Dwelling Time and Berth Occupancy Ratio in \\ The Tegalsari Fishing Port
}

Suryanto, Ignatius Tri Hargiyatno, Sandi Wibowo dan Setiya Triharyuni

\section{ABSTRAK}

Jumlah kapal yang melakukan kunjungan di PPP Tegalsari meningkat dari tahun ke tahun, hingga pada tahun 2014 mencapai 4.237 unit kedatangan kapal yang membawa total hasil tangkapan 48 ribu ton. Salah satu masalah yang banyak dikeluhkan nelayan adalah lamanya waktu tunggu dan bongkar, hingga harus bermalam. Berdasarkan rencana induk PPP Tegalsari, diharapkan pada tahun 2020 memiliki panjang dermaga bongkar sepanjang 1.323 meter disamping prasarana

\section{ABSTRACT}

The number of vessels visiting coastal fishing port (PPP) of Tegalsari has been increased from year to year. In 2014, there were 4,232 vessels arrived and loaded 48 million tons of catches on the port. Length of dwelling time became the major problem causing nights delay. According to the master plan of PPP Tegalsari, it is planned that they will have a 1,323 meter of loading dock and other supporting facilities by 2020. This research was conducted in 2014 and it aims to find alternative 
lain yang mendukung. Penelitian yang dilaksanakan tahun 2014 ini bertujuan untuk mencari alternatif solusi di samping pengembangan dermaga sesuai rencana induk tersebut. Alternatif solusi tersebut didapatkan dengan melakukan reka ulang proses produksi PPP Tegalsari Tahun 2014 dengan bantuan perangkat lunak Arena versi 5 "Student Version". Hasil studi menunjukan tingkat pemakaian dermaga skenario rencana induk tidak ekonomis karena hanya 10,7\%. Dikawatirkan kinerja dermaga tersebut akan semakin merosot dengan diberlakukannyanya Permen KP No.2 Tahun 2016 tentang pelarangan penggunaan pukat hela (trawl) dan pukat tarik (seine nets). Studi memberikan alternatif solusi yang lebih bersifat sosial ekonomi dengan meningkatkan jumlah tenaga buruh bongkar dan pemecah es menjadi $200 \%$ dari semula dengan tetap menggunakan dermaga bongkar yang ada saat ini. Dampak dari solusi tersebut waktu kerja buruh menjadi lebih sesuai dengan UU Ketenagakerjaan No. 13 Tahun 2003, serta dwelling time rata-rata menurun dari 75,3 menjadi 59,3 jam/kapal atau penurunan $21 \%$.

Kata Kunci: dwelling time, utilitas tenaga kerja, kinerja dermaga, rencana induk, PPP Tegalsari solutions more than development of the dock which is already stated in the master plan. The alternative solution was obtained by simulating the production process of PPP Tegalsari based on 2014 fishing vessel arrival using the software of student version of Arena 5. The result showed that the dock occupancy ratio of the master plan is not economical because it is only $10.7 \%$. It could be worsen with the enactment of the Marine and Fisheries Ministerial Regulation No.2/2016 on the prohibition of trawls and seine nets fishing. This study provides a more socio-economic alternative solution by increasing the number of unloading and ice-crushing workers to 200\% from the 2014 condition using the existing berth. The solution gives a positive impact on worker's working time which is conformed with Labour Law No. 13/2003. In addition, average of dwelling time decreased from 75.3 to 59.3 hour/vessel or $21 \%$ decreas.

Keywords: dwelling time, labour utility, berth occupancy ratio, masterplan, Coastal fishing port Tegalsari

\title{
PEMBERDAYAAN PENGOLAH IKAN SKALA RUMAH TANGGA DI PROVINSI JAWA BARAT
}

\section{The Empowerment of Small Scale Fish Processors in West Java Province}

\author{
Yaya Hudaya, Aida Vitayala S. Hubeis, Basita G. Sugihen dan Anna Fatchiya
}

\section{ABSTRAK}

Pemberdayaan pengolah ikan di Provinsi Jawa Barat dilakukan dengan tujuan untuk meningkatkan kesejahteraan pelaku usaha, menjamin keamanan pangan produk yang dihasilkan, dan ikut menjaga kelestarian sumber daya ikan yang ada. Tujuan penelitian ini adalah untuk menganalisis kinerja pemberdayaan pengolah ikan skala rumah tangga dan dampaknya di Provinsi Jawa Barat. Metode analisis menggunakan uji beda Man Whitney $U$. Hipotesis penelitian ini adalah ada perbedaan nyata proses pemberdayaan pengolah ikan dan dampaknya di pesisir utara Kabupaten Cirebon dan selatan Kabupaten Sukabumi, Provinsi Jawa Barat. Hasil penelitian menunjukkan tidak ada perbedaan nyata proses pemberdayaan pengolah ikan dan dampaknya baik di pesisir utara Kabupaten Cirebon maupun di pesisir selatan Kabupaten Sukabumi. Kebijakan pemberdayaan pengolahan ikan skala rumah tangga di Provinsi Jawa Barat baik di pesisir utara maupun selatan tidak perlu dibedakan. Namun, intensitas pemberdayaan terutama penyuluhan perikanan, bantuan peralatan dan modal usaha perlu ditingkatkan lagi.

Kata Kunci: pemberdayaan, kesejahteraan, rumah tangga, pengolahan ikan

\section{ABSTRACT}

Empowerment of fish processors in West Java Province was carried out in order to improve well-being of the fish processors, ensuring food security of the product, and maintaining sustainability of the fish resource. The purpose of this study was to analyze performance of the empowerment of small scale fish processors and its related impact in the West Java Province. The analytical method used different test Man Whitney U. Hypothesis of this research was that there was a significant difference between the process of fish processing empowerment and its related impact in the north coast of Cirebon District and in the south coast of Sukabumi district of West Java Province. The results indicated that there was no significant difference between the process of fish processing empowerment and its impact both in the north coast of Cirebon and in the south coast of Sukabumi. Hence, policy on empowerment small scale fish processing household in both north and south coast districts of West Java Province can be treated the same. However, the intensity of empowerment, especially in terms of fisheries extension, equipment and business capital assistance need to be improved.

Keywords: empowerment, welfare, household, fish processing 


\title{
PERAN PEREMPUAN NELAYAN DALAM USAHA PERIKANAN TANGKAP DAN PENINGKATAN EKONOMI RUMAH TANGGA PESISIR TELUK JAKARTA
}

\section{Role of Fisher's Woman in Fishery Business and Improvement of The Household's Economy in The Coastal Bay of Jakarta}

\author{
Nurlaili dan Rizky Muhartono
}

\begin{abstract}
ABSTRAK
Teluk Jakarta memiliki wilayah pesisir yang menjadi salah satu sumbermata pencaharian. Salah satu aktor pada wilayah pesisir adalah kaum perempuan. Perempuan pesisir memiliki peran penting dalam rumah tangga nelayan. Pada aktivitas ekonomi rumah tangga, perempuan pesisir ikut berkontribusi bahkan terkadang mendominasi. Tulisan ini menggambarkan peran perempuan nelayan dalam rumah tangga nelayan pesisir Teluk Jakarta. Penelitian dilakukan di Teluk Jakarta di dua kecamatan yaitu Cilincing dan Penjaringan, tiga Kelurahan di Cilincing (Marunda, Cilincing dan Kalibaru) dan dua kelurahan di Penjaringan (Kamal Muara dan Muara Angke). Metode analisa data yang digunakan adalah metode deskriptif kualitatif dengan teknik pengumpulan data adalah wawancara terstruktur, wawancara mendalam (indepth interview), observasi dan diskusi kelompok terbatas (Focus Group Discussion/ FGD). Kajian studi literatur juga dilakukan untuk memperkaya tulisan. Perempuan pesisir Teluk Jakarta memiliki peran dalam aktivitas usaha perikanan. Pada usaha perikanan tangkap, perempuan berperan pada tahap persiapan yaitu mempersiapkan perbekalan melaut (ransum) dan membantu perbaikan jaring, pasca melaut yaitu memilah hasil tangkapan ikan dan memasarkannya. Pada kegiatan budidaya kerang hijau, perempuan pesisir di Teluk Jakarta berperan pada tahap pasca panen yaitu memilah kerang hijau, mengupas (memipil), merebus dan memasarkannya. Pada usaha pengolahan hasil perikanan, perempuan pesisir Teluk Jakarta berperan pada keseluruhan proses pengolahan ikan dan pemasarannya. Peran perempuan yang strategis dalam tiap tahapan kegiatan usaha perikanan menjadikan perempuan sebagai titik tumpu dalam program pembangunan. Melihat besarnya peran perempuan dalam kegiatan usaha perikanan, maka dalam setiap program pemberdayaan masyarakat di pesisir Teluk Jakarta harus melibatkan perempuan.
\end{abstract}

Kata Kunci: peran, perempuan, pesisir, Teluk Jakarta

\section{ABSTRACT}

Jakarta Bay has a coastal area of which become one of the sources of livelihood. One of the actors in coastal areas is women. Coastal women play significant role in the fisher's household. They contribute even dominate the fishers daily household activities. This paper describes the role of women fishers in the coastal of Jakarta Bay. The research was conducted in Jakarta Bay in two sub-districts (Cilincing and Penjaringan), three urban villages in Cilincing (Marunda, Cilincing and Kalibaru) and two urban villages in Penjaringan (Kamal Muara and Muara Angke). Data were collected through structured interview, in depth interview, observation and focus group discussion. Data were analyzed using qualitative descriptive method. Furthermore, this paper enriched with literature review. Coastal women of Jakarta Bay play significant roles in fishery business activity. In the capture fisheries, they prepare food and supplies before sailing and help repairing the net, thereafter, they sort the fish catch and sell them. Women also play their role in shellfish cultivation especially in the post-harvest stage such as sorting out the green shell, peeling, boiling and selling. While in the processing business of fishery products, the women of Jakarta Bay coast play their role in the whole process of fish processing and its marketing. Therefore, women in Jakarta Bay become a fulcrum of the development program, and it is necessary to involve women in every community empowerment program on the coast of Jakarta Bay.

Keywords: actor, woman, coastal areas, Jakarta Bay 


\title{
DAMPAK KEBERADAAN INDUSTRI SEMEN TERHADAP SISTEM MATA PENCAHARIAN (LIVELIHOOD SYSTEM) NELAYAN BAYAH
}

\section{The Impact of The Cement Industry to The Livelihood System of Bayah Fishers}

\author{
Yunia Rahayuningsih
}

\section{ABSTRAK}

Keberadaan industri semen di Kecamatan Bayah seperti dua sisi mata uang logam, memiliki dampak positif dan negatif tertentu bagi masyarakat sekitar, khususnya terhadap mata pencaharian nelayan Bayah. Penelitian ini bertujuan untuk mendeskripsikan kondisi mata pencaharian nelayan sebelum dan sesudah adanya industri semen, dan mengidentifikasi strategi adaptasi untuk menjamin keberlanjutan mata pencaharian di kalangan nelayan. Metode yang digunakan yaitu deskriptif kualitatif dengan nelayan sebagai key informan. Data didapatkan melalui kuesioner, wawancara mendalam, Focus Group Discussion (FGD), dan observasi lapangan. Hasil penelitian menunjukkan bahwa masuknya industri semen (PT. Cemindo Gemilang) di Kecamatan Bayah membawa perubahan berantai, baik dari perubahan ekologis maupun kehidupan sosial ekonomi nelayan. Perubahan ekologis menyebabkan bergesernya daerah tangkapan ikan, perubahan ketersediaan produk perikanan sebagai modal utama, peningkatan biaya dalam mengakses sumber daya, dan berimplikasi pada pendapatan rumah tangga nelayan. Ketidakpastian penghasilan seringkali ditanggulangi dengan diversifikasi mata pencaharian, yang merupakan salah satu bentuk strategi nafkah ganda yang sudah dilakukan oleh nelayan Bayah sebelum adanya industri semen. Namun setelah adanya industri semen membuka peluang untuk bekerja di sektor non perikanan yaitu sebagai buruh pabrik dan kuli panggul di dermaga. Strategi adaptasi untuk menjamin keberlanjutan mata pencaharian dilakukan melalui adaptasi berupa penganekaragaman sumber pendapatan, penganekaragaman alat tangkap, perubahan daerah tangkapan, dan memanfaatkan hubungan sosial.

Kata Kunci: dampak, industri semen, sistem mata pencaharian, nelayan bayah

\section{ABSTRACT}

The existence of cement industry in Bayah Subdistrict is like two sides of the same coin, it has a positive and negative impacts for the surrounding community, especially on the livelihood of Bayah fishers. This study aims to describe the livelihood conditions of fishers before and after the cement industry exists in their village as well as to identify adaptation strategies to ensure the sustainability of fishers livelihoods. The study used descriptive qualitative method involving fishers as the key informant. Data were collected through questionnaires, in-depth interviews, FGD, and field observations. Results showed that the existence of cement industry (PT. Cemindo Gemilang) in Bayah Sub-district brought about a series of change toward ecological and socioeconomic life of the fishers. Ecological change led to shifting of catchment areas, changes in the availability of fisheries product as their major capital, increased costs of access to resources, and implications toward household incomes. Uncertainty of income was frequently solved by varying livelihoods, and it was one of strategies that has been implemented by Bayah fishers even before the cement industry exists. However, the existence of cement industry has created job opportunity in non-fishery sector such as factory workers and dock porters. Adaptation strategies to ensure the sustainability of their livelihood are: diversification of sources of income, diversification of fishing gear, relocation of fishing area and empowerment of social relationship.

Keywords: impact, cement industry, livelihood system, fishers of bayah 


\title{
ANALISIS FAKTOR-FAKTOR YANG MEMPENGARUHI PERUBAHAN PENDAPATAN NELAYAN AKIBAT VARIABILITAS IKLIM (Kasus: Desa Muara Kecamatan Blanakan Kabupaten Subang) Analysis of The Factors Affecting The Change in Fisher's Income Due To Climate Variability (Case: The Village of Muara, subdistrict of Blanakan, Subang District)
}

\author{
Azizi, Eka Intan Kumala Putri dan Achmad Fahrudin
}

\begin{abstract}
ABSTRAK
Variabilitas iklim seperti curah hujan serta kondisi perairan dengan tinggi gelombang dan angin yang kuat mempengaruhi aktivitas nelayan di laut dalam melakukan operasional penangkapan. Kondisi ini mengakibatkan perubahan pendapatan dari para nelayan. Penelitian ini dilakukan di Desa Muara Kecamatan Blanakan Kabupaten Subang bertujuan untuk mengetahui perubahan pendapatan serta faktor-faktor yang mempengaruhinya. Jumlah responden penelitian 100 orang terdiri dari 70 orang nelayan lokal, 15 nelayan pendatang dari Brebes dan 15 nelayan pendatang dari Tuban. Metode yang digunakan adalah analisis pendapatan dan regresi berganda. Hasil penelitian menunjukkan bahwa rerata perubahan pendapatan nelayan lokal jaring insang Rp.1.753.681 (10,41\%), nelayan lokal jaring payang sebesar Rp.14.321.631 (22,05\%), nelayan andon Brebes Rp.11.430.833 $(23,56 \%)$ dan nelayan andon Tuban Rp.25.342.333 $(22,24 \%)$. Sedangkan faktor-faktor yang mempengaruhi perubahan pendapatan nelayan adalah jarak menangkap, jumlah jam kerja di laut, dummy hujan dan dummy tinggi gelombang.
\end{abstract}

Kata Kunci: andon, nelayan, pendapatan, variabilitas iklim

\section{ABSTRACT}

Fish capture is heavily influenced by climate variability such as rainfall, water level and winds. Such conditions affect the fishers' income. This research was conducted at Muara Village, Blanakan Sub-District, Subang Regency, and its purpose was to identify the change of income and factors contributing income changes. This research collected data from 100 respondents consist of 70 of local fishers, 15 of andon fishers from Brebes and 15 of andon fishers from Tuban. Method of the study was income analysis and a multiple linear regression. The research found that average number of local fishers' income with gills nets was IDR $1,753,681$ (10.41\%), local fishers with payang nets is IDR 14,321,631 (22.05\%), andon fishers from Brebes was IDR $11,430,833$ (23,56\%), and andon fishers from Tuban was IDR 25,342,333 (22,24\%). Factors that contribute to the income changes were distance of fishing area, sailing hours, rain dummy and wave height dummy.

Keywords: andon, climate variability, fisher's, income

\section{INDEKS SOSIAL EKONOMI RUMAH TANGGA NELAYAN INDONESIA}

\section{Socio Economics Index of Fisher Household in Indonesia}

\section{ABSTRAK}

Indeks Sosial Ekonomi merupakan indeks komposit yang menunjukkan kondisi sosial ekonomi rumah tangga berdasarkan tiga aset modal, yaitu modal finansial, modal sumberdaya manusia dan modal sosial. Tujuan penelitian ini adalah mengetahui perbedaan kondisi sosial ekonomi nelayan berdasar kelas armada. Metode yang digunakan merupakan modifikasi dari kerangka sustainable livelihood dengan analisis secara deskriptif. Berdasarkan hasil analisis diketahui bahwa nilai indeks yang terbesar terletak pada kelas armada 11-30 GT. Data ini menunjukkan bahwa nelayan pada kelas tersebut memiliki kondisi sosial ekonomi yang lebih baik. Namun demikian, semakin besar ukuran armada tidak selalu menunjukkan hubungan yang positif karena nilai indeks yang terkecil justru terjadi pada kelas armada 5-10 GT. Oleh karena itu pengembangan usaha nelayan berdasarkan kelas armada akan lebih baik bila dikembangkan pada dua kelas yaitu kurang dari 5 GT atau 11-30 GT.

Kata Kunci: nelayan, skala kecil, sosial ekonomi, modal finansial, modal sumberdaya manusia, modal sosial
ABSTRACT

The socio-economic index is a composite index showing the socio-economic conditions of households based on three capital assets namely financial capital, human capital and social capital. The purpose of this research is to understand the difference of socio-economic condition of fisher based on fleet class. The method used is a modification of the sustainable livelihood framework with the analysis conducted descriptively. Based on the analysis results, it is known that the largest index value lies in the class of 11-30 GT fleet. These data indicate that fisher in those classes have better socioeconomic conditions. However, the larger the size of the fleet does not always show a positive relationship because the smallest index value actually occurs in the 5-10 GT fleet class. Therefore, the development of fishing business based on fleet class will be better if developed in two classes that is less than 5 GT or 11-30 GT..

Keywords: fisher, small scale, socio economics, financial capital, human capital, social capital 


\section{(Indeks Pengarang)}

(Author Index)

Apituley, Yolanda M.T.N

$121-132$

Erlina, Mei Dwi

$31-44$

Fariyanti, Anna

$107-120$

Firdaus, Maulana

$21-30$

Hiariey, Johanis

$121-132$

Hikmah

$11-20$

Koeshendrajana, Sonny

$1-10$

Luhur, Estu Sri

$93-105$

Mira

$11-20$

Prihantini, Campina Illa

$107-120$

Rahadian, Rikrik

$57-73$

$75-91$

Ramadhan, Andrian

$1-10$

Risakotta, Stacia C.

$121-132$

Saptanto, Subhechanis

$11-20$

$75-91$

Siahainenia, Stevanus M.

$121-132$

Suryawati, Siti Hajar

$1-10$

$31-44$

Suwarti

$21-30$

Syaukat, Yusman

$107-121$

Tajerin

$57-73$

$75-91$

Talakua, Eygner G

$45-56$

Wardono, Budi

$57-73$

Yusuf, Risna

$93-105$ 
(Indeks Subjek)

(Index Subject)

Ambon

$93-105$

Blue ocean strategy ..

$57-73$

Buton Selatan

$31-44$

Cakalang

$93-105$

EFE

$31-44$

Faktor produksi

$47-58$

GERPARI

$59-75$

IFE

$31-45$

Ikan asap

$123-134$

Industrialisasi

95-107

IPM

21-30

Karang

$11-20$

Keberadaan

$11-20$

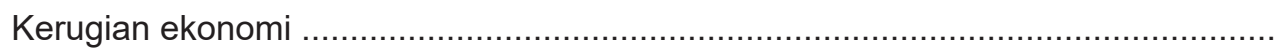

Kompensasi

$1-10$

Konsumen

$121-132$

21-30

Koordinasi fungsional

$121-132$

Kota Ambon

$75-91$

$45-56$

Maksimasi keuntungan

$11-20$

Manfaat langsung

$11-20$

Manfaat tidak langsung

$57-73$

Model bisnis canvas

$75-91$

Model GTAP

$93-105$

Nilai tambah

$75-91$

Non-tarif

$45-56$

Optimasi

$57-73$

Pakan ikan mandiri

$107-121$

Perbandingan keuntungan

$1-10$

Pesisir dan laut

$21-30$

Pesisir

$31-44$

Prioritas strategi

$31-44$

Rantai nilai

$93-105$

RKPD

$21-30$

Rumput laut

$31-44$

Sektor ekonomi

$75-91$

Sektor perikanan

$75-91$

Sikap dan perilaku

$121-131$ 
Sistem bagi hasil

$107-120$

SWOT .

$31-44$

Tumpahan minyak ....

$1-10$

Usaha budidaya rumput laut

$45-56$

Usaha garam rakyat

$107-120$

Valuasi ekonomi

$1-10$ 


\section{JURNAL SOSIAL EKONOMI KELAUTAN DAN PERIKANAN \\ Pedoman Bagi Penulis}

Jurnal Sosial Ekonomi Kelautan dan Perikanan memuat hasil-hasil penelitian yang berkaitan dengan penelitian bidang sosial dan ekonomi kelautan dan perikanan. Naskah yang diterima yaitu karya tulis yang merupakan karya asli dan belum pernah diterbitkan dipublikasi lainnya.

\section{UMUM}

Kertas : HVS A4 $(21,0 \times 29,7 \mathrm{~cm})$

Margin : Kiri $3 \mathrm{~cm}$

Bawah, Kanan dan Atas $2 \mathrm{~cm}$

Huruf : Arial, 11 pt, hitam, 1,5 spasi. ketik dalam Bahasa Indonesia (kecuali abstrak) atau Bahasa Inggris yang baik dan benar, tidak diperkenankan menggunakan singkatan yang tidak umum.

Struktur : Judul, Abstrak, Pendahuluan, Metodologi, Hasil dan Pembahasan, Kesimpulan dan Implikasi Kebijakan, Ucapan Terima Kasih dan Daftar Pustaka

Naskah dikirim melalui Online di alamat web http://ejournal-balitbang.kkp.go.id index.php/sosek atau alamat ke Redaksi Pelaksana Jurnal Sosial Ekonomi Kelautan dan Perikanan, Gedung Balitbang KP I, Komplek Bina Samudera, JI. Pasir Putih I Ancol Timur, Jakarta 14430, telp (021) 64700924, fax (021) 64711583, Email: pt.sosek@gmail.com

\section{PENULISAN NASKAH}

Naskah ditulis rapi dengan panjang naskah maksimum 20 halaman (termasuk gambar dan tabel) dan setiap lembar tulisan diberi nomor halaman.

\section{Judul}

Judul harus ditulis secara ringkas (maksimal 15 kata), tetapi cukup informatif untuk menggambarkan isi tulisan. Ditulis dalam Bahasa Indonesia dan di bawahnya dalam Bahasa Inggris, menggunakan huruf Arial, kapital Bold, 12 pt, center.

\section{Penulis dan institusi}

Penulis dan Institusinya ditulis berurutan di bawah judul. Nama penulis ditulis dengan huruf Arial, kapital bold, $10 \mathrm{pt}$, center. Institusi asal (alamat, nomor telepon, nomor faksimil, serta e-mail) ditulis dengan huruf Arial, kapital dan kecil, 10 pt, center.

\section{Abstrak}

Ditulis dalam bahasa Indonesia dan bahasa Inggris, tidak lebih dari 200 kata dan hanya satu paragraf. Abstrak memberikan informasi singkat namun jelas tentang alasan penelitian dilakukan, tujuan yang ingin dicapai, metode yang digunakan, hasil yang diperoleh serta kesimpulan. ditulis dengan huruf Arial, 10 pt.

\section{Kata Kunci}

Ditulis dalam Bahasa Indonesia dan Inggris, terdiri dari 4 sampai 6 kata tulis di bawah abstrak.

\section{Pendahuluan}

Pendahuluan sebaiknya dimulai dengan menjelaskan latar belakang penelitian, perumusan masalah, kerangka teoritis, dan tujuan penelitian yang dibuat secara ringkas. 


\section{Metodologi}

Diuraikan secara rinci dan jelas mengenai lokasi dan waktu penelitian, bagaimana data diperoleh dan sumbernya serta bagaimana metode analisis datanya, jika metode yang digunakan telah diketahui sebelumnya harus dicantumkan acuannya.

\section{Hasil dan Pembahasan}

Bagian ini menyuguhkan data dan informasi yang ditemukan peneliti serta dipakai sebagai dasar penyimpulan bahkan penyusunan teori baru. Secara umum disuguhkan secara bertahap dalam tiga bagian: uraian temuan data dan informasi yang terkumpul. Sertakan data pendukung yang berupa tabel, grafik dan gambar seperlunya untuk memperjelas dan mempersingkat uraian yang harus diberikan.

\section{Kesimpulan dan Implikasi Kebijakan}

Kesimpulan diuraikan secara ringkas dan jelas mengacu pada pokok-pokok bahasan serta kemampuan mengartikulasikan temuan pokok untuk rekomendasi kebijakan, ditulis secara singkat dan jelas dalam dua atau tiga kalimat Pada intinya menegaskan apakah tujuan penelitian ini sudah tercapai atau masih ada hal-hal yang belum dicapai. Bila belum, jelaskan apa penyebabnya.

\section{Ucapan Terima Kasish}

Ucapan Terima Kasih Ditulis dengan formal, ucapan diberikan pihak tertentu, misalnya Sponsor penelitian, nama yang benar-benar terlibat dalam pelaksanaan penelitian dan ucapan tidak terlalu berlebihan.

\section{Daftar Pustaka}

Dicantumkan dalam naskah bila ada pengutipan dari sumber lain. Proporsi daftar pustaka yang diacu yaitu $80 \%$ merupakan rujukan primer dan merupakan terbitan 5 tahun terakhir. Tuliskan hanya pustaka yang dirujuk dalam makalah saja. Hindari pustaka yang bersumber pada majalah, koran, atau media lainnya yang non-ilmiah. Disusun berdasarkan abjad.

\section{Buku :}

Huda, H.M., R.A. Wijaya dan S. Koeshendrajana. 2011. Dinamika Perkembangan Sosial Ekonomi Usaha Rumah Tangga Petambak Garam. In Koeshendrajana (eds.), PANELKANAS: Dinamika Perkembangan Usaha, Pendapatan dan Konsumsi Rumah Tangga. Badan Riset Kelautan dan Perikanan. Jakarta

\section{Prosiding :}

Solihin, A., S. Koeshendrajana dan F. Y. Arthatiani. 2012. Harmonisasi Hukum Internasional Dalam Pemberantasan IUU Fishing dan Implementasinya dalam Peraturan Perundang-undangan Indonesia. In Isnansetyo et al. (eds.), Prosiding Seminar Nasional IX Tahun 2012., SE-04: 1-17. Jurusan Perikanan Fakultas Pertanian UGM. Yogyakarta.

\section{Jurnal IImiah :}

Pitcher, T.J. and D.B Preikshot. 2001. Rapfish: A Rapid Appraisal Technique to Evaluate the Sustainability Status of Fisheries. Fisheries Research. Vol 49(3): 255-270

\section{Artikel dari situs internet ;}

Sahyuti. 2012. Ciri-ciri Masyarakat Adat. http://syahyutivariabel.blogspot.com/2012/07/ciri-ciri-masyarakat-adat.html. (diakses 27 Desember 2012). 


\section{Laporan :}

Koeshendrajana, S., F. N. Priyatna, I. Mulyawan, A. Ramadhan, E. Reswati, R. Triyanti, A. Fahrudin, E. S. Kartamihardja dan C. M. Witomo. 2008. Riset Identifikasi, Karakterisasi dan Valuasi Sosial Ekonomi Sumber daya Perairan Umum Daratan. Laporan Teknis Kegiatan Penelitian. Balai Besar Riset Sosial Ekonomi Kelautan dan Perikanan. BRKP

Thesis, Disertasi :

Sufii, S. 2008. Konvergensi Ekonomi Regional di Indonesia Tahun 1985-2006. Thesis. Fakultas Ekonomi. Universitas Indonesia. Program Magister Perencanaan dan Kebijakan Publik. Jakarta

Tabel

Judul tabel (Arial, center, \& $11 \mathrm{pt}$ ) diberi nomor urut dan ditulis di atas tabel. Tabel ditulis dalam bahasa Indonesia dan Inggris, diketik menggunakan program MS-Word dan tidak dalam bentuk JPEG. Sumber dicantumkan di bawah tabel.

Contoh:

Tabel 8. Total Nilai Ekonomi Mangrove di Wilayah Pesisir Kabupaten Merauke.

Table 8. The Total Economic Value Mangrove Coastal Merauke.

\begin{tabular}{lrr}
\hline \multicolumn{1}{c}{$\begin{array}{c}\text { Kategori Nilai Ekonomi/ } \\
\text { Category Economic Value }\end{array}$} & $\begin{array}{c}\text { Total Nilai/ } \\
\text { Total value (Rp/Tahun) }\end{array}$ & $\begin{array}{c}\text { Total Nilai/ } \\
\text { Total value (Rp/Ha/Tahun) }\end{array}$ \\
\hline Nilai Guna Langsung/ Direct value & $121,120,873,947$ & $11,964,919$ \\
Nilai Guna Tidak Langsung/ Indirect Value & $48,361,817,303,4$ & $4,777,419$ \\
Nilai Pilihan/ Option value & $3,074,276,220$ & 303,692 \\
Nilai Keberadaan/ The existence value & $2,134,333,320$ & 210,840 \\
Nilai Pewarisan/ Value Inheritance & $2,728,107,120$ & 269,496 \\
\hline \multicolumn{1}{c}{ Total/ Total } & $\mathbf{1 7 7 , 4 1 9 , 4 0 7 , 9 1 0}$ & $\mathbf{1 7 , 5 2 8 , 3 6 7}$ \\
\hline
\end{tabular}

Sumber/ Source : Data Primer Diolah (2015)/ Primary Data Processed (2015)

\section{Gambar}

Judul Gambar (Arial, center, \& 11 pt) diberi nomor urut dan ditulis di bawah Gambar. Gambar ditulis dalam bahasa Indonesia dan Inggris, diketik menggunakan program MS-Word dan dalam bentuk JPEG dengan kualitas gambar resolusi diatas $72 \mathrm{dpi}$. Sumber dicantumkan di bawah judul.

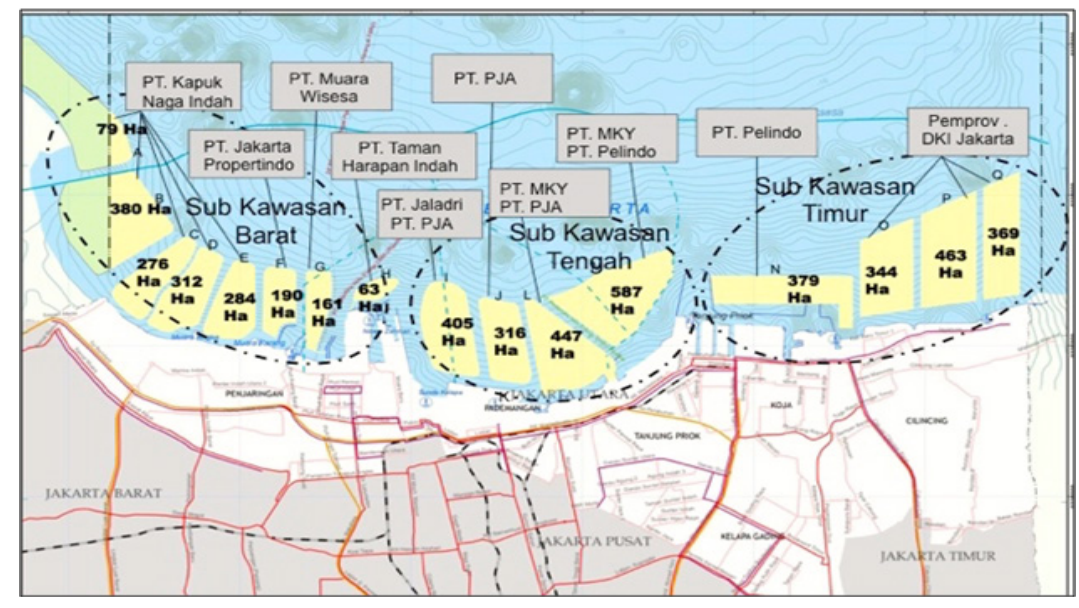

Gambar 1. Peta Wilayah Reklamasi Teluk Jakarta

Figure 1. Map of Reclamation Area of Jakarta Bay

Sumber: Kementerian Lingkungan Hidup dan Kehutanan (KLHK) dalam Mongabay/ Source: Ministry of Environmental and Forestry in Mongabay (2016) 

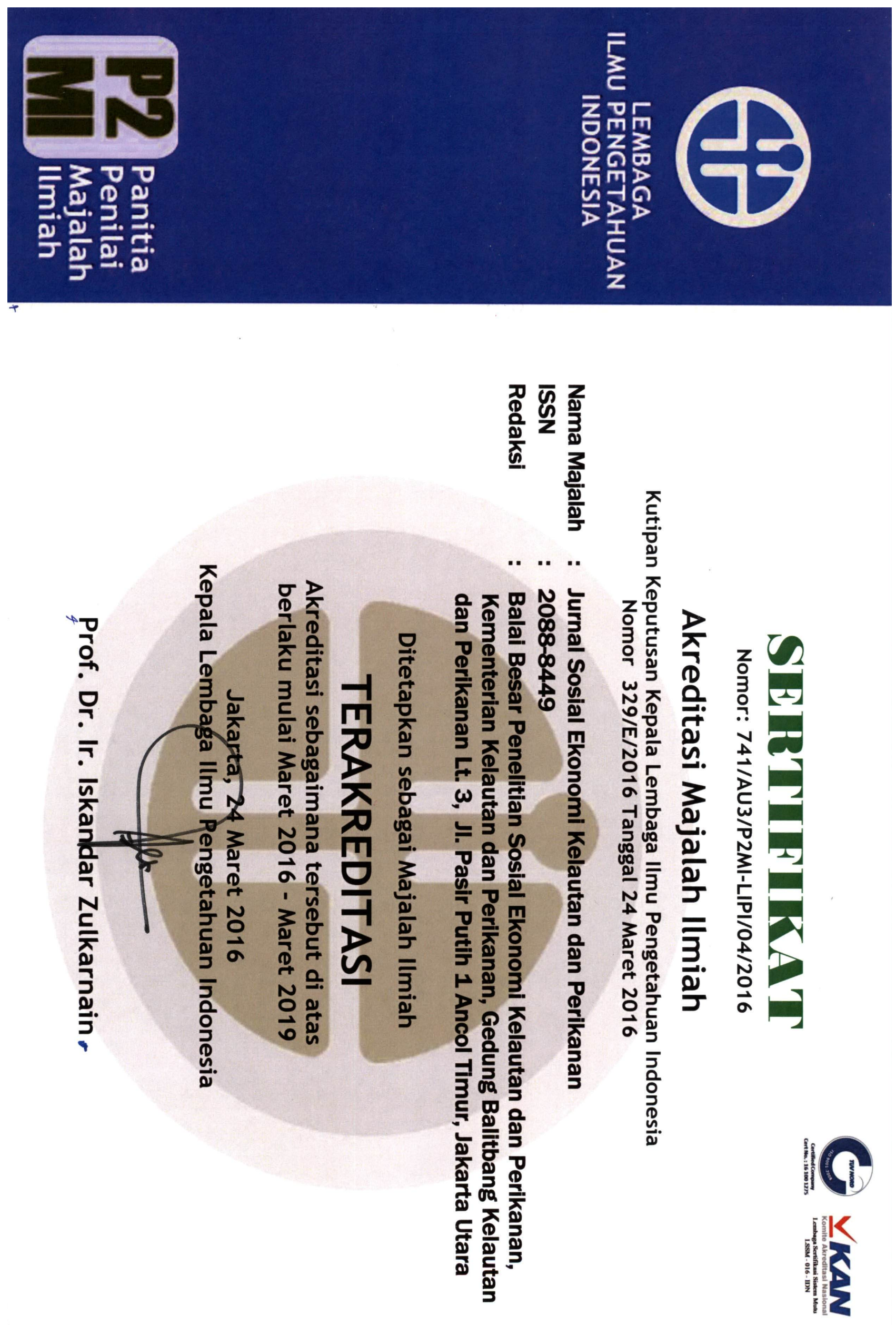
Web : www.bbrse.kkp.go.id

email :pt.sosek@gmail.com 